\title{
PLANNING, PRELIMINARY DESIGN, AND INITIAL PERFORMANCE OF THE NAGS HEAD BEACH NOURISHMENT PROJECT
}

\author{
Timothy W. Kana PhD, $\mathrm{PG}^{1}$ and Haiqing Liu Kaczkowski PhD, $\mathrm{PE}^{1}$
}

\begin{abstract}
A 3.5 million cubic meter beach nourishment project was completed along 16 kilometers of shoreline at Nags Head, North Carolina, 32 kilometers south of the US Army Corps of Engineers Field Research Facility at Duck. The project is the largest locally-funded nourishment accomplished to date in the United States. Three ocean-certified hopper dredges and one cutterhead suction dredge constructed the project between May and October 2011. This paper discusses the planning, design, and initial performance of the project. Nags Head is exposed to high waves from the northeast which generate net southerly transport over the long term. A key design issue for the project was the large gradient in erosion rates from north to south. Fill sections were varied accordingly based on documented volume erosion rates and model simulations for the area. Permitting involved over five years of environmental reviews because of the need to work during fair-weather summer months in the relatively high-energy setting. The design also built on prior work in connection with a federal nourishment project scheduled for the area if and when funds become available. Two offshore areas strategically located close to south Nags Head were utilized for construction which proceeded efficiently under summer waves until late August when Hurricane Irene impacted the area. The hurricane and fall northeast storms produced rapid adjustment of the construction profile but no net loss of sand from the project area. Post-project surveys show initial profile equilibration was largely confined to the inshore zone inside the 3.7 meter (m) [ -12 foot (ft) NAVD] contour. Depth of closure at decadal scales is estimated to be $-7.3 \mathrm{~m}(-24 \mathrm{ft}$ NAVD).
\end{abstract}

Keywords: beach nourishment, Nags Head NC, volumetric erosion, offshore borrow area, dredging

\section{INTRODUCTION}

A 3.5-million cubic meter $(\mathrm{mcm})$ (4.6-million cubic yard, mcy) beach nourishment project was completed at Nags Head, North Carolina, USA, between 24 May and 27 October 2011 (Fig 1). This was the first large scale beach restoration along the "Outer Banks", a chain of barrier islands which define the central East Coast of the United States. This paper summarizes the planning, preliminary design, and initial performance of the project. A companion paper (Kaczkowski \& Kana, this volume) discusses the final design and application of relevant coastal engineering models. Quantities given herein are in metric units with certain amounts in English units for purposes of consistency with the original source documents.

The 16.1-kilometer $(\mathrm{km})$ project (final construction length $=10.0$ miles) is located $\sim 32 \mathrm{~km}$ south of the US Army Corps of Engineers (USACE) Field Research Facility (FRF) at Duck, a site familiar to many researchers. Nags Head is within the same NNW-SSE trending shoreline bight, with Oregon Inlet situated $8 \mathrm{~km}$ to the south. Chesapeake Bay entrance is $100 \mathrm{~km}$ to the north.

The predominant wave direction is northeast, exposing Nags Head to some of the highest wave energy along the US East Coast (Leffler et al 1996) with average deep-water wave heights exceeding 1.6 meters $(\mathrm{m})$ every ten days (1942-1988-source Dolan et al 1988). Lowest wave energy occurs in June, July, and August when prevailing southwesterly winds are directed offshore. During fall and winter, upward of 20 percent of observed waves exceed $1.5 \mathrm{~m}$ (CSE 2011).

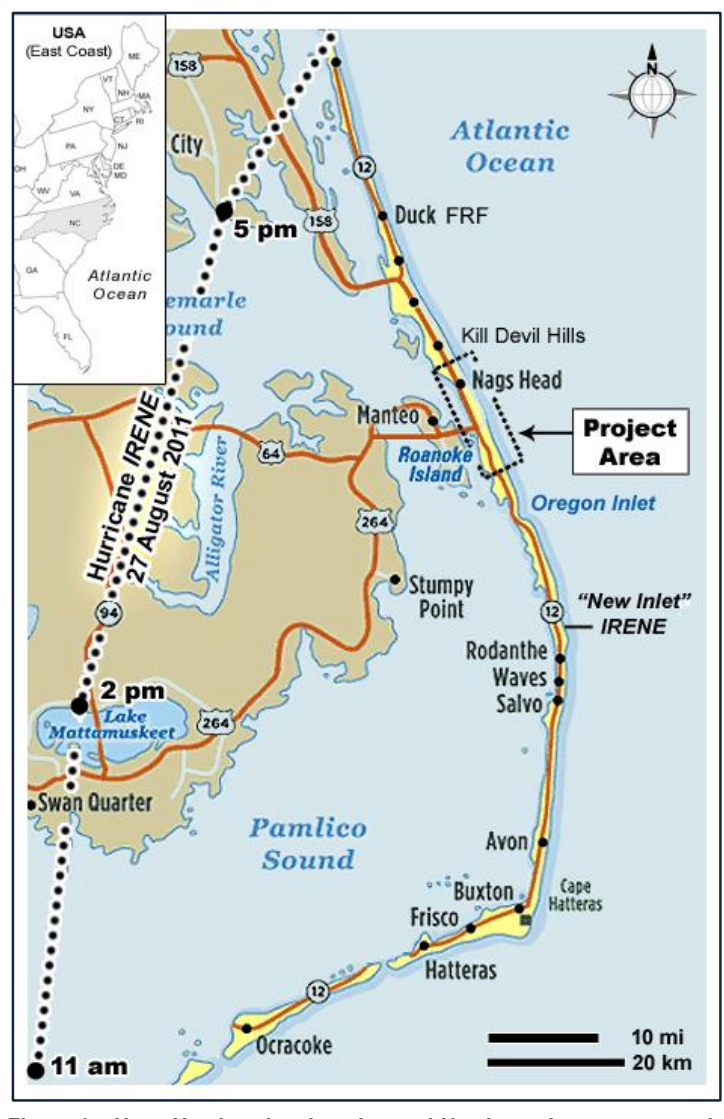

Figure 1. Nags Head project location and Hurricane Irene storm track 27 August 2011.

\footnotetext{
${ }^{1}$ Coastal Science \& Engineering, Inc. PO Box 8056, 160 Gills Creek Parkway, Columbia, South Carolina, 29202 USA
} 
Predicted 100-year storm tides at Nags Head are 3.0 m NAVD (North American Vertical Datum -source USACE 2000). Surges within Pamlico Sound, a major shallow water lagoon protected by the Outer Banks, can be significant and trigger barrier breaches in areas where a healthy foredune is absent, as was the case during Hurricane Irene on 27 August 2011 along Pea Island and Rodanthe (Clinch et al 2012).

The principal design issues associated with the Nags Head beach nourishment project included:

- Determination of the average annual volumetric erosion rates, particularly the gradients of change alongshore.

- Calculations of the volume deficit with respect to an ideal or target profile volume.

- Identification and confirmation of suitable borrow area(s).

- Obtaining permits for hopper dredging outside the normal environmental protection windows.

- Formulation of a restoration plan meeting the goals, objectives, and budget of the local community.

\section{PRIOR STUDIES}

The USACE (2000) developed a "50-year" erosion control plan for Nags Head which called for an initial nourishment of $\sim 6.15 \mathrm{mcm}$ and average renourishment of $\sim 0.73 \mathrm{mcm}$ per year $(\mathrm{mcm} / \mathrm{yr})$. This formulation implicitly assumes an annual loss rate of $\sim 44$ cubic meters per meter per year $\left(\mathrm{m}^{3} / \mathrm{m} / \mathrm{yr}\right)$ over the $16.3-\mathrm{km}$ federal project length. The English equivalent is $\sim 18 \mathrm{cy} / \mathrm{ft} / \mathrm{yr}$. Because of likely delays in federal funding for construction and the critically eroded condition of many sections of beach (Fig 2), the town of Nags Head elected to proceed with an interim beach restoration project. Coastal Science \& Engineering (CSE) was retained by the Town in 2005 to develop a plan for nourishment consistent with prior federal studies, including an approved Final Environmental Impact Statement (FEIS) which is mandated under the National Environmental Policy Act (NEPA). The USACE (2000) plan established the boundaries for the interim project and facilitated certain design analyses. CSE also benefitted from extensive coastal processes research at the nearby FRF, and regional sand resource studies by USACE (2000) and the US Minerals Management Service (e.g. Byrnes et al 2003).

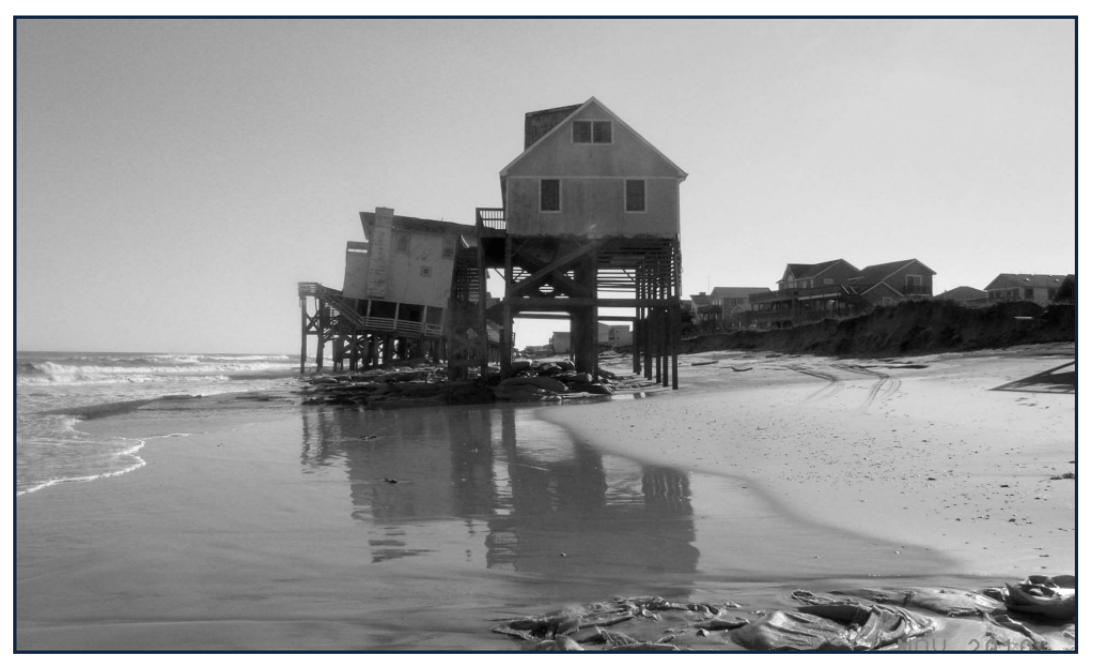

Figure 2. Abandoned houses in the surf zone in south Nags Head at mid tide November 2010. Photo by PA McKee.

\section{EROSION ANALYSIS AND DESIGN NOURISHMENT VOLUME}

USACE (2000) completed what is believed to be the first comprehensive condition survey of the beach and inshore zone along Nags Head in 1994 using a baseline and profiles at $\sim 300 \mathrm{~m}(1,000 \mathrm{ft})$ spacing. No comparative profiles were available for the original federal plan so projections of annual loss rates were based on modeling and linear shoreline change rates. Official "50-year" erosion rates, based on aerial photography, range from 0.6 meters per year $(\mathrm{m} / \mathrm{yr})$ to $\sim 2.0 \mathrm{~m} / \mathrm{yr}$ with a strong gradient from north to south (Fig 3) (NCDENR 1998, 2004). Many cottages in the central historic district have been moved inland on their lots since the late 1800s despite a moderate rate of shoreline retreat of $<1$ $\mathrm{m} / \mathrm{yr}$. The south-most $\sim 4 \mathrm{~km}$ experience higher recession of up to $\sim 2 \mathrm{~m} / \mathrm{yr}$ at the town line, $8 \mathrm{~km}$ from 


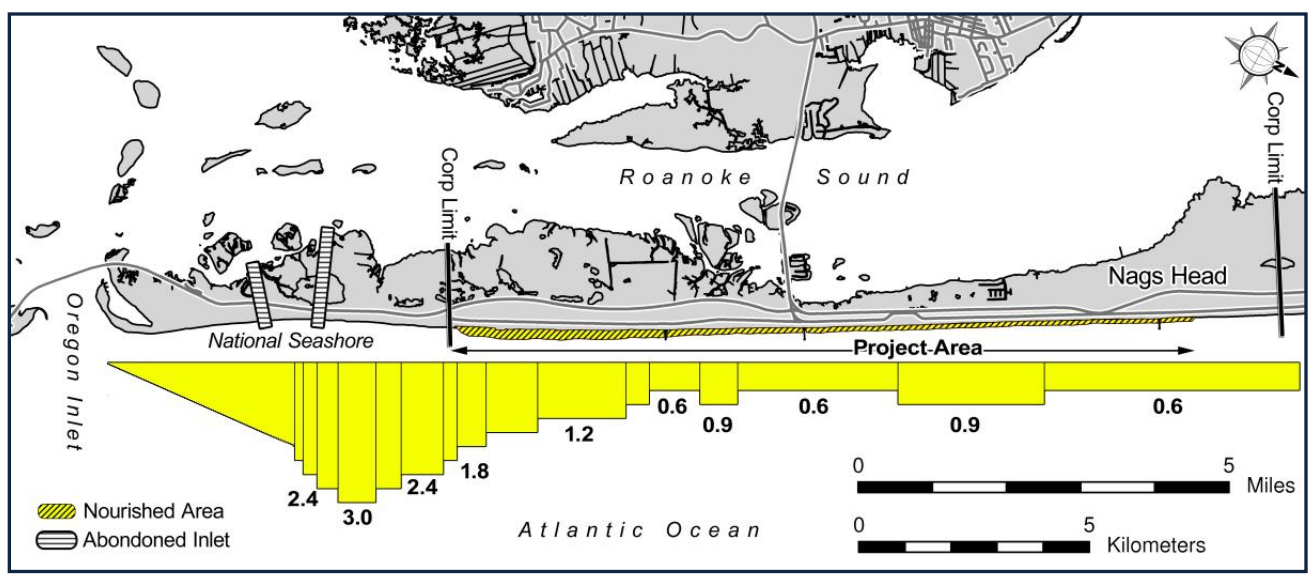

Figure 3. Official 50-year erosion rates based on aerial photography showing large gradients in the vicinity of south Nags Head and nearby abandoned inlets that have been closed for at least 200 years. [After NCDENR 1998, 2004]

Oregon Inlet. The undeveloped shoreline segment from Nags Head to the inlet exhibits increasing to diminishing erosion rates as shown in Figure 3. This "signature of erosion" (Kana 1995) with large gradients of change along the updrift shoreline near tidal inlets is similar to other sites such as western Fire Island, New York.

Focused erosion between south Nags Head and Oregon Inlet is likely associated with abandoned inlets. As ebb-tidal deltas migrate (or become abandoned due to a channel avulsion), the shoals leave prominent salients which become a focus of wave attack leading to a diffusion of sediment away from the bulge. Shoreline recession increases along the area of the bulge relative to adjacent sections of beach. Two former inlets reportedly discharged through the barrier spit more than 200 years ago (Fisher 1962). As Figure 3 illustrates, the majority of the project area has 50-year recession rates in the range $0.6-0.9 \mathrm{~m} / \mathrm{yr}$. It can be shown that $1 \mathrm{~m}$ of beach recession is roughly equivalent to 10 cubic meters per meter $\left(\mathrm{m}^{3} / \mathrm{m}\right)$ of volumetric change across the profile to the normal limit of measurable change along many U.S. East Coast beaches (Dean 2002).

CSE re-established the USACE baseline and resurveyed the 1994 profile lines in 2005 for purposes of computing decadal volume changes. The results were used to delineate five discrete reaches with differing loss rates. Volume changes were computed for various cross-shore lenses including the principal recreation zone of the beach (foredune to $-1.8 \mathrm{~m}$ NAVD) and the inshore zone (to $-5.8 \mathrm{~m}$ NAVD). The latter limit incorporates the longshore bar but generally excludes offshore topography associated with shore-oblique ridges, relict features of the continental shelf (Swift et al 1973). The results yielded an estimate of average annual volume losses totaling $\sim 0.21 \mathrm{mcm} / \mathrm{yr}(\sim 0.272$ $\mathrm{mcy} / \mathrm{yr}$ ) for the period 1994 to 2005 (Fig 4). Subsequent surveys by CSE yielded lower net volume losses and provided further evidence for the local depth of closure (DOC) at decadal scales (Fig 5). Results of DOC estimates for individual profiles ranged from $5.8 \mathrm{~m}$ to $10.7 \mathrm{~m}$ with the average equaling $7.3 \mathrm{~m}$. Birkemeier (1985) reported DOC for FRF in the range $7.5-9 \mathrm{~m}$. CSE adopted a DOC of $5.8 \mathrm{~m}(-19 \mathrm{ft})$ NAVD for project formulation and planning purposes given the goal of providing interim nourishment for a relatively short ten-year period. A DOC of $7.3 \mathrm{~m}$ is estimated for long-term beach response at scales $>10$ years.

Unit profile volumes to the adopted DOC were computed for purposes of evaluating the relative condition of each section of beach (see Fig 4). Normally, the formulation for nourishment should involve some initial volume to restore the profile and achieve a desired beach condition or geometry, plus an advance volume to anticipate average annual losses under a design life (Verhagen 1992, Kana 1993, Dean 2002). For the interim Nags Head project, CSE's formulation was based simply on the replacement volume plus a safety factor. There were several reasons for this approach. First, the gradients in erosion from north to south along the project area were extremely high. The deficit volumes by reach were relatively small compared with the average sand losses along south Nags Head. Secondly, limited funds and certain construction logistics for the project precluded incorporation of a protective dune or storm berm meeting a particular design criteria (i.e. based on storm-return period). Thirdly, experience from other nourishment sites suggested that a wide dry-sand beach would quickly promote backbeach buildup and dune growth (e.g. Bocomazo et al 2011). 


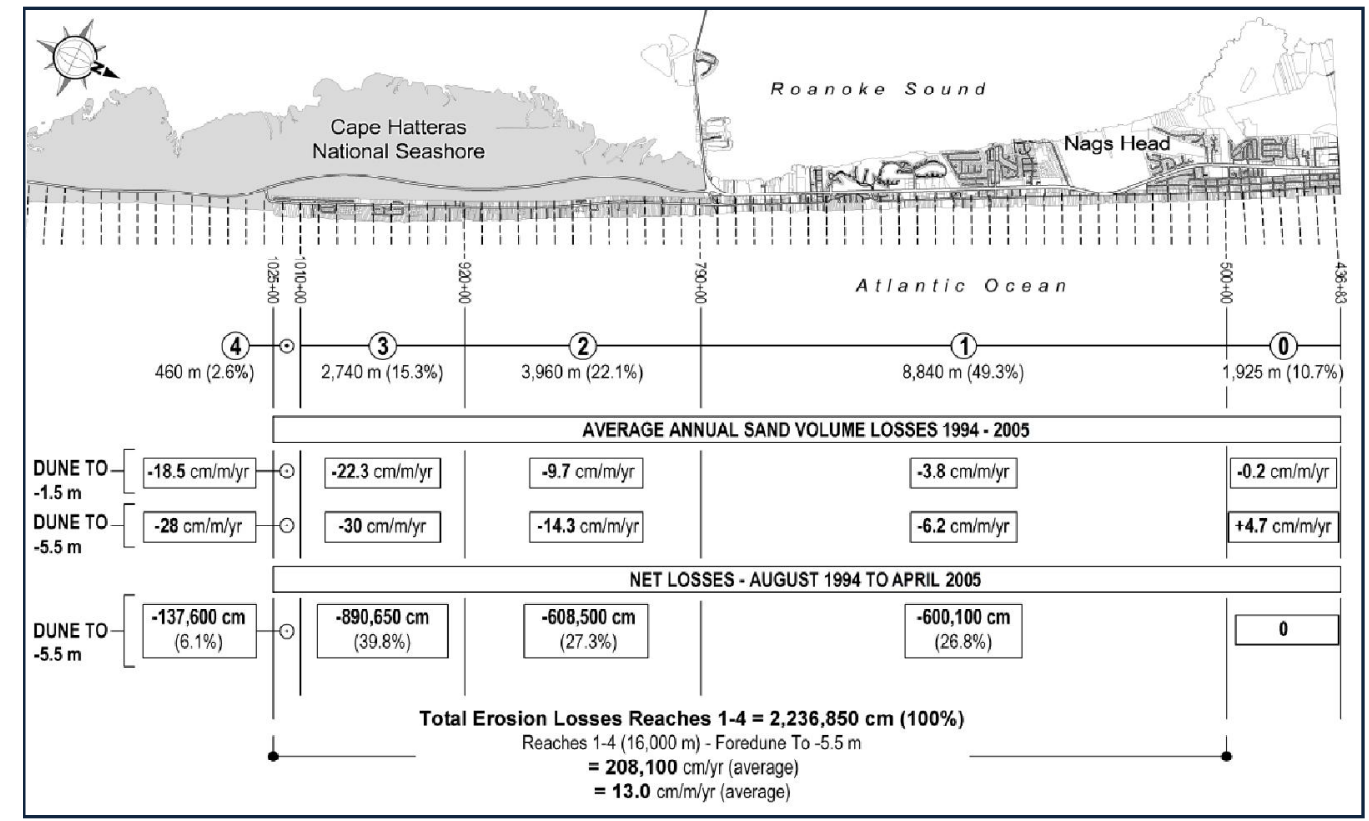

Figure 4. Volumetric erosion rates (cm-cubic meters) for Nags Head project reaches for the period 1994 to 2005. Stationing is in feet. Datum is NAVD.

The initial formulation for an interim project on which permit applications were based, called for $\sim 3 \mathrm{mcm} \pm 15$ percent based on ten years of erosion losses at $0.21 \mathrm{mcm} / \mathrm{yr}$ plus an $\sim 50$ percent safety factor. The ten-year base volume $(\sim 3 \mathrm{mcm})$ was half the initial volume proposed under the federal plan (USACE 2000). Because of uncertainties in construction costs, particularly for sites that have not been nourished previously, CSE's standard practice is to assume prices and volumes may fluctuate +15 percent from budgeted amounts. This provides flexibility in project approval under a fixed budget once bids for construction are received. Thus, the interim Nags Head project was projected to entail placement of $\sim 2.7-3.5 \mathrm{mcm}(3.4-4.6 \mathrm{mcy})$ at a cost of ( $\sim)$ US $\$ 28-35$ million (CSE unpublished). The projected fill density was varied by reach to account for the gradients in volume losses (see Kaczkowski \& Kana, this volume, for details of the final design). For planning and permitting purposes the anticipated unit volumes ranged from $\sim 95 \mathrm{~m}^{3} / \mathrm{m}$ to $375 \mathrm{~m}^{3} / \mathrm{m}$ with the highest fill density along Reach 3. The actual range of unit construction volumes was $110-430 \mathrm{~m}^{3} / \mathrm{m}$, or an average of $\sim 215 \mathrm{~m}^{3} / \mathrm{m}$ over the $16.1-\mathrm{km}$ project length.

\section{NOURISHMENT SEDIMENT QUALITY}

\section{Native Beach Sediment}

Nags Head beach was sampled according to criteria for native beach characterization established by the North Carolina Coastal Resources Commission. Surficial sediment samples were obtained at 14 transects (1.6 km spacing) with 6 samples each above mean low water (MLW) and seven samples each from MLW to $-6 \mathrm{~m}$. The results show gradients in the cross-shore and longshore directions, characteristic of a barred shoreline. The subaerial beach consists of medium sand $(\sim 0.3-0.5$ millimeter $-\mathrm{mm})$; the inner plunge point of the surf zone contains coarse sand with local concentrations of granules (2.0-4.0mm) and "pea gravel"; and the inshore zone including the bar is typically fine sand $(0.2 \mathrm{~mm})$. Sediments generally fine from north to south (Fig 6). The overall mean grain size is 0.31 $\mathrm{mm}$.

CSE's standard practice is to weight subaerial samples more heavily for purposes of nourishment planning because that better reflects the area of beach in need of repair. Thus, two adopted native-grain sizes were applied for sediment compatibility analyses: $0.36 \mathrm{~mm}$ (omits three sample positions seaward of MLW) and $0.47 \mathrm{~mm}$ (omits five sample positions seaward of MLW). Nags Head beach sediments are predominantly quartz with minor percentages of feldspar and heavy minerals (e.g. garnet) and $<2$ percent shell material $\left(\mathrm{CaCO}_{3}\right)(\mathrm{CSE} 2011)$. 

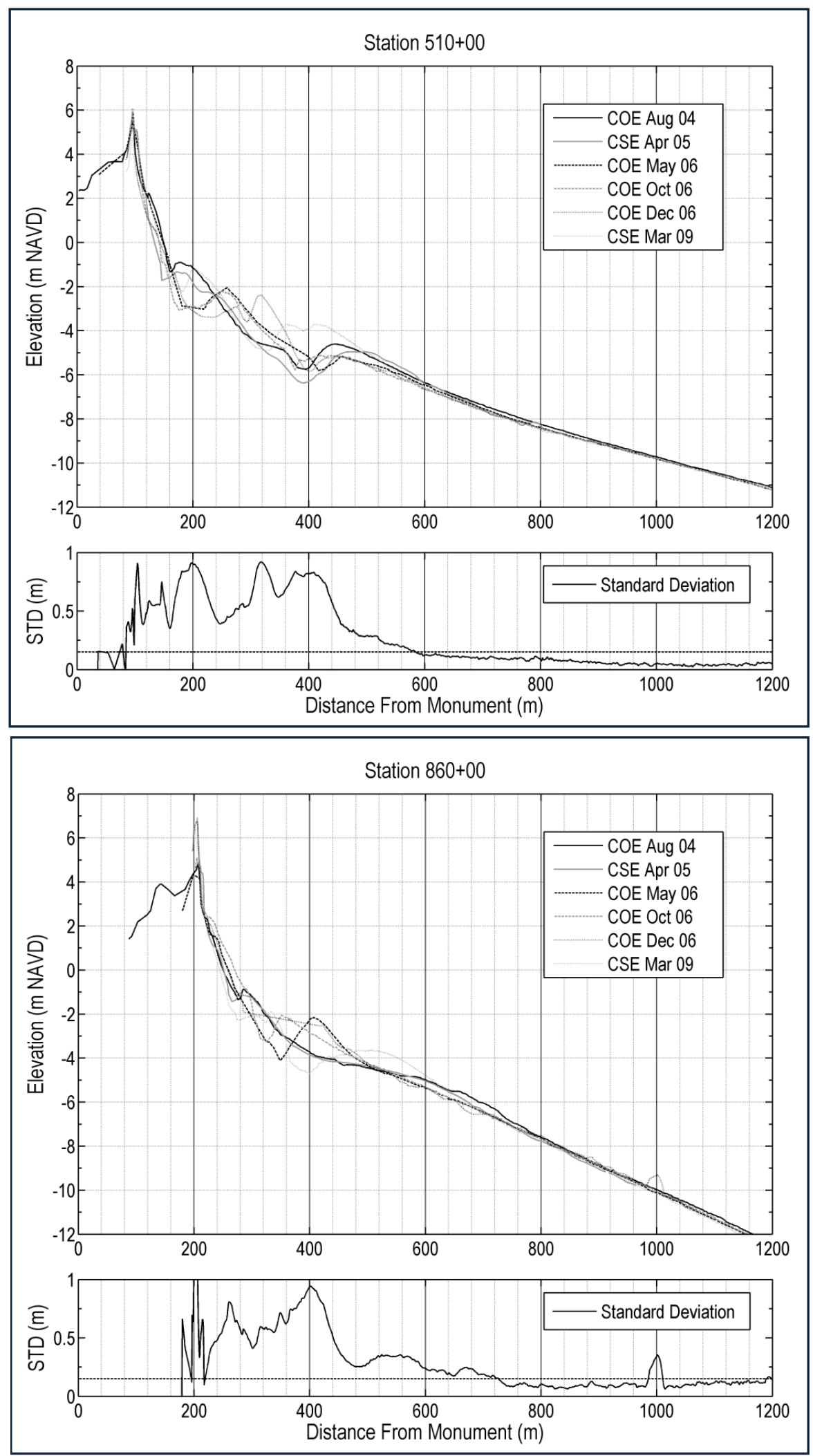

Figure 5. Representative profiles (2004-2009) for two Nags Head stations showing inferred DOC equaling $\sim 6.3$ $\mathrm{m}$ to $6.7 \mathrm{~m}$, the depths at which the standard deviation of elevation among individual profiles falls below $0.15 \mathrm{~m}$. 

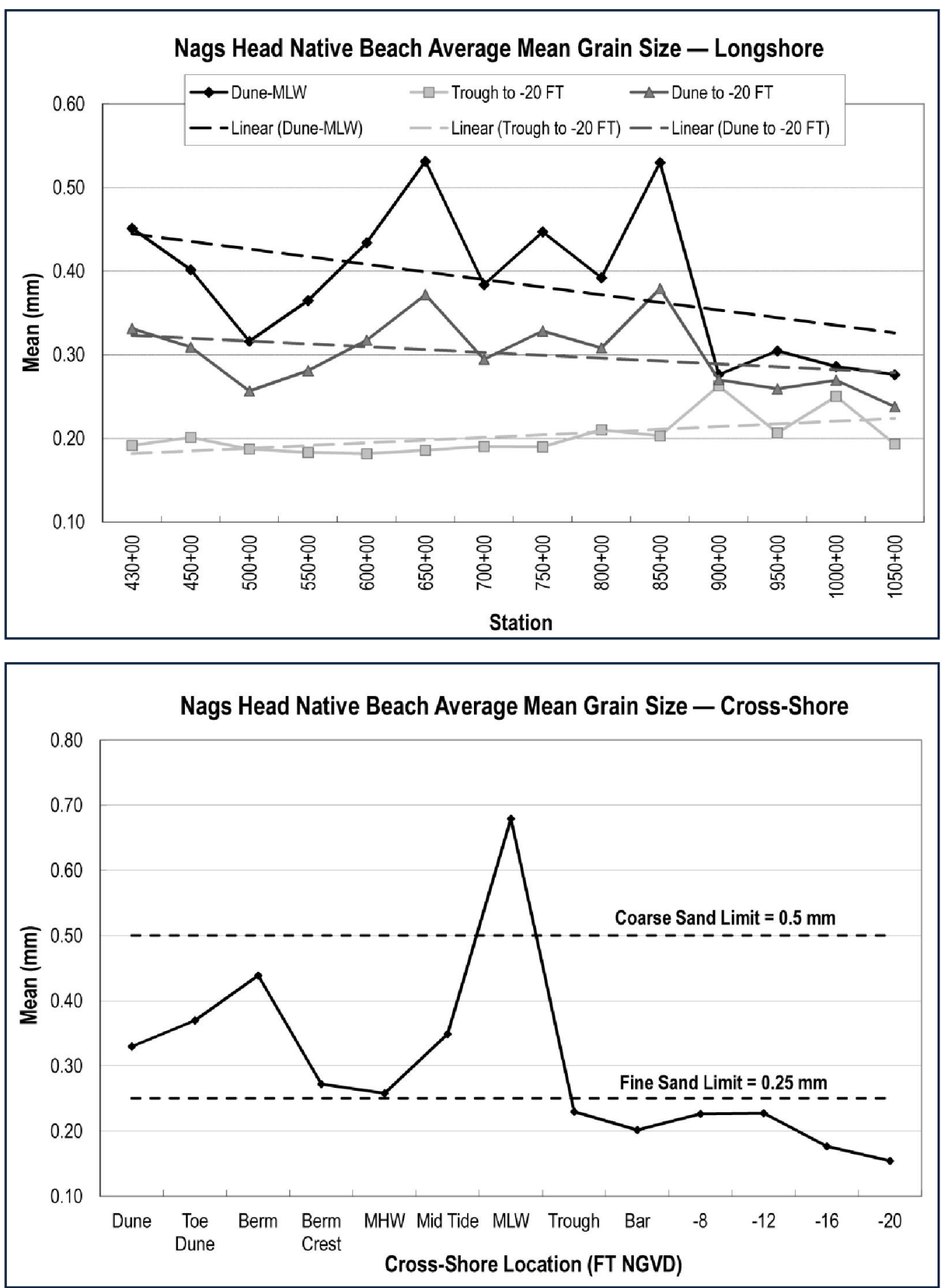

Figure 6. Trend in mean grain size alongshore and cross-shore for selected groups of surficial samples. See Figure 4 for stationing in English units of feet. Depths in feet NGVD, which is about $0.3 \mathrm{~m}(\sim 1 \mathrm{ft})$ below NAVD. [Source: CSE 2011] 


\section{Borrow Area Confirmation}

USACE (2000) delineated a large offshore area (S1) containing upward of 75 $\mathrm{mcm}$ of beach-quality sand for potential use in federal projects. CSE conducted additional geotechnical surveys over portions of S1 for purposes of confirming sediment quality and compatibility with the native beach. Using a proprietary coring device, CSE initially obtained 61 borings averaging $2.5 \mathrm{~m}$ long within S1. Cores were logged and sampled for standard sediment analysis. Isopach maps of mean grain size, percent mud, percent shell, and percent gravel were prepared using a custom MATLAB ${ }^{\mathrm{TM}}$ program to facilitate delineation of borrow subareas. Three areas were delineated then further sampled with 41 additional borings for a core density ranging between 4.4 and 8.8 hectares (ha) per core (Fig 7). The total area of all three potential borrow subareas was $\sim 420$ ha. Sediment compatibility was determined using the James (1975) overfill factor $\left(R_{A}\right)$ for each subarea and a range of assumed dredging excavation depths between $0.6 \mathrm{~m}$ and $2.4 \mathrm{~m}$. The potential sand reserves in each subarea were computed to the reference depth. Areas 2 and 3 , combined, were determined to contain $\sim 6$ mcm over a 2.4-m section, or approximately twice the volume required for the project. The composite $\mathrm{R}_{\mathrm{A}} \mathrm{S}$ were close to 1.0 , and composite mean grain sizes were $0.43 \mathrm{~mm}$ and $0.42 \mathrm{~mm}$ (respectively) for subareas 2 and 3 (CSE 2011). On average, 97 percent of each core sample was in the sand-size range with granular material $(>2 \mathrm{~mm}$ ) ranging from 2 to 3 percent, shell material ranging from 0.9 to 1.7 percent, and mud present in trace amounts $(<0.1$ percent $)$.

The borrow subareas were centered $\sim 2.8-$ $3.8 \mathrm{~km}$ offshore in water depths between $12 \mathrm{~m}$ and $18 \mathrm{~m}$. Both areas were situated directly off south Nags Head, the area requiring the highest fill density. Subarea 3 was positioned closer to shore for possible use by a pipeline dredge. Subarea 2 was a long narrow borrow area for use by self-propelled hopper dredges.

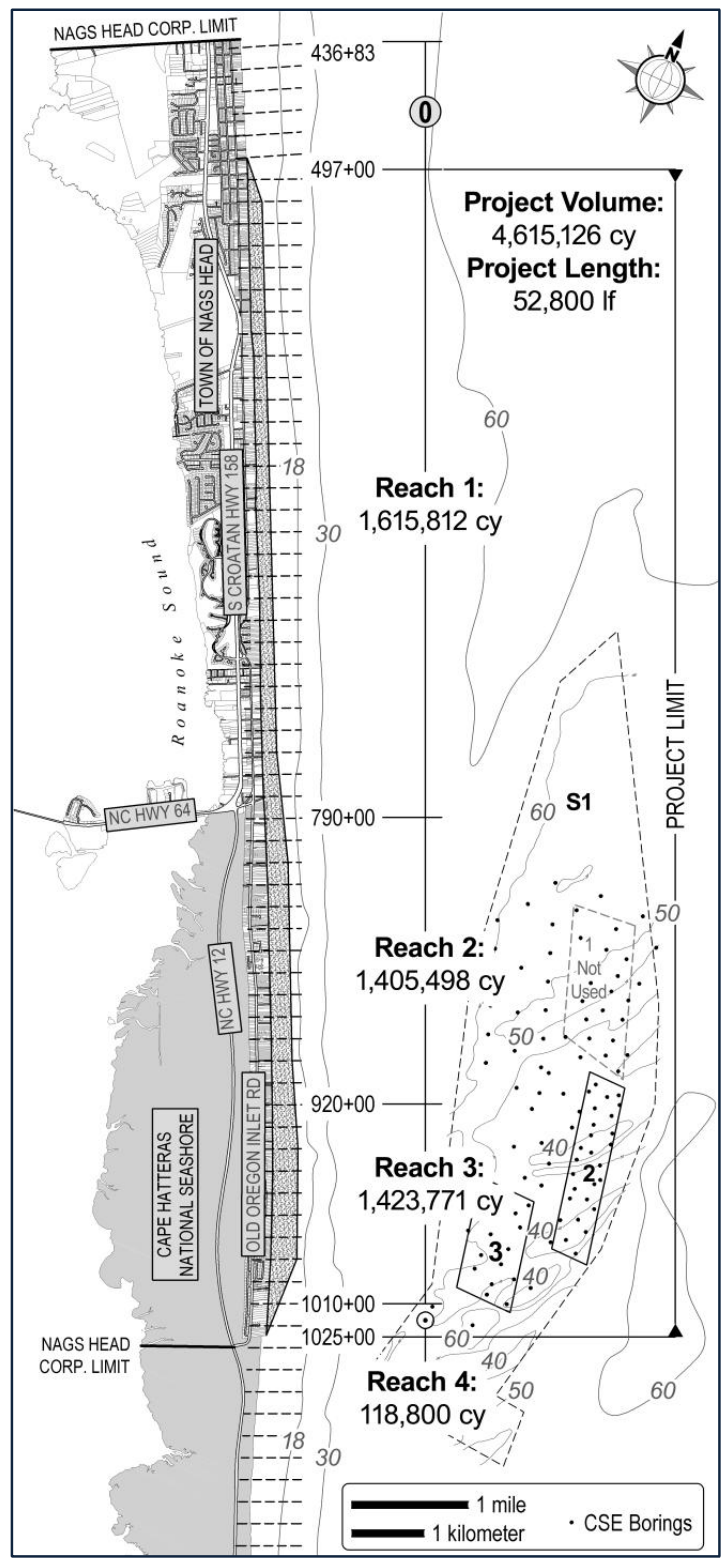

Figure 7. Project borrow areas 2 and 3 within USACE S1 were excavated by one cutterhead suction dredge and three hopper dredges (GLDD) between 24 May and 27 October 2011. Volumes placed by reach are given in English units (cubic yards) for consistency with project documents. [Depths shown in feet NAVD] Subarea 1 (shown as "not used" on Fig 7) was eliminated from consideration because the other subareas contained sufficient volume for the project.

The overall quality of borrow sediments was a close match with the native beach in terms of sediment color, grain size, and concentration of gravel and shell. [See Kana et al (2012) for additional information.] Mud was negligible in the cores for both areas, and turbidity was low in the water column suggesting the offshore area of south Nags Head is subject to high wave energy as well as lack of fine-grain inputs. The principal source of mud for the inner shelf in this region is the Chesapeake Bay plume which discharges at the bay entrance $100 \mathrm{~km}$ north of Nags Head (Boicourt et al 1987). There is no riverine input in the vicinity of the project area.

Oregon Inlet was considered as a potential borrow source because it is the site of frequent channel maintenance by USACE. Preliminary sampling of inlet channel sediments indicated the material 
would not perform as well as $\mathrm{S} 1$ sediments because it tested in the fine-to-medium sand range (Fig 8). Overfill factor $\left(\mathrm{R}_{\mathrm{A}}\right)$ for inlet sand samples averaged $>7.0$ (CSE 2011). The other issues precluding use of inlet sediments were the long pumping distances from the inlet to the project area $(8-24 \mathrm{~km})$, shallow channel depth $(<4 \mathrm{~m})$ precluding access via ocean-certified hopper dredges, and the lower channel maintenance volumes available for dredging compared with the project design volume.
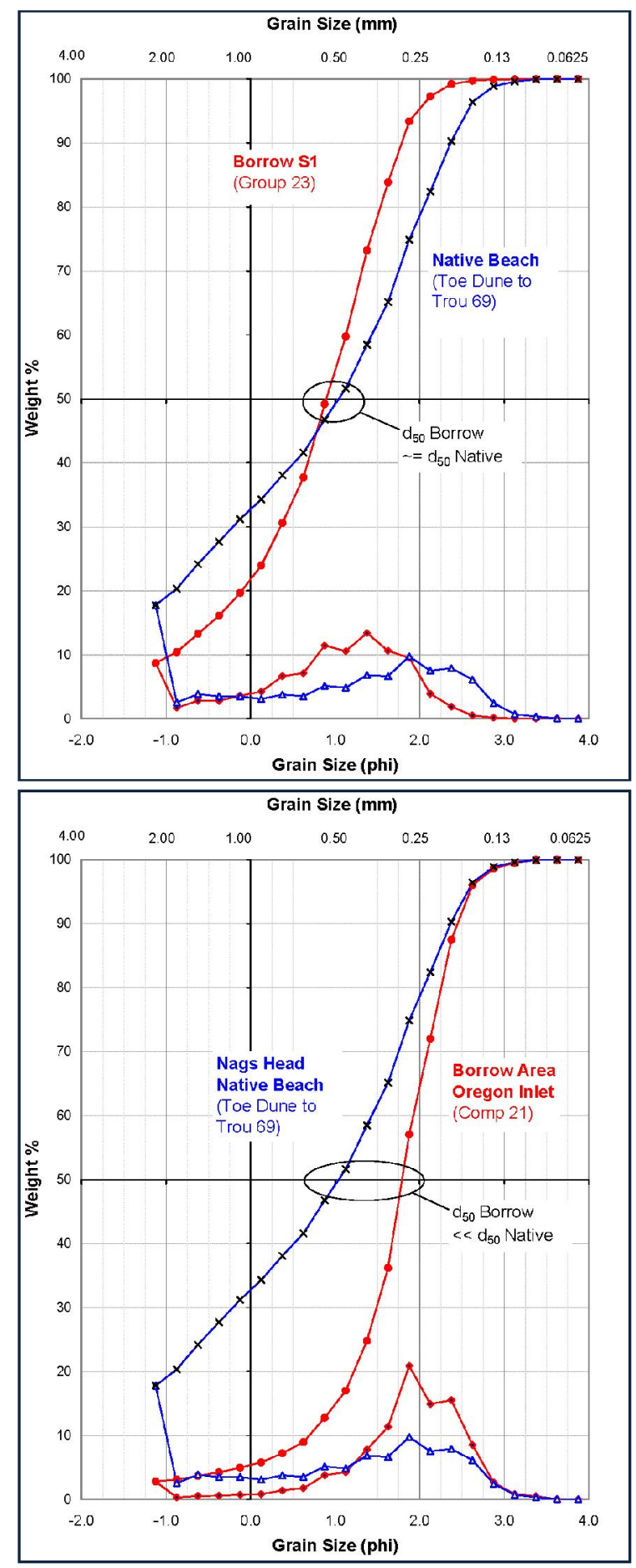

Figure 8. Representative composite grain-size distributions (frequency and cumulative frequency) for native beach and two potential borrow areas (circle points on each graph). Note better match for the offshore "S1" samples. Oregon Inlet sediments, dredged for routine channel maintenance, are considerably finer than the Nags Head native beach. 


\section{PERMITTING AND CONSTRUCTION PLANNING}

The Nags Head beach nourishment project required permits from state and federal authorities, based on comprehensive environmental impact statements (EIS). Extra environmental documentation of impacts was required because of the need to accomplish construction during summer when wave conditions are favorable for offshore dredging. High waves and frequent northeasters during fall and winter severely limit operations and pose unacceptable hazards, which were the paramount concern (R Smith, Weeks Marine; W Hanson, GLDD-pers comm, March 2007). According to US dredging contractors, offshore operations become problematic for cutterhead dredges under $\sim 1 \mathrm{~m}$ or higher wave conditions. Hopper dredging operations are generally suspended during $\sim 1.5 \mathrm{~m}$ or higher waves (B Holliday, Dredging Contractors of America, per comm, February 2007).

The principal environmental issue at Nags Head was sea turtle nesting. As part of the Southeast (USA) Region, Nags Head is subject to the same turtle protection measures and "take statements" as Florida, where the majority of nests are located (NMFS 1997). Virginia Beach (80 km north of Nags Head) is situated along the same shoreline bight, but is under the environmental protection rules of the Northeast (USA) Region, where turtle nesting is of less concern. Virginia Beach conducted two nourishment events during summer months utilizing hopper dredges and offshore borrow areas (CSE 2011). The Southeast Region take statements severely limit the use of hopper dredges because of the likelihood of encountering turtles. Nags Head, situated near the northern limit of sea-turtle nesting range, has an average of $<0.1$ nests per kilometer per year along the project shoreline (USACE 2010). By comparison, South Carolina beaches average $\sim 10$ nests per kilometer each year (Hopkins-Murphy 1999).

Environmental reviews resulted in considered delays in project approval, finally culminating with permits issued in late 2010-five years after the initial application. Mitigation for summer dredging was required as a condition of permits, including nightly monitoring on the beach during construction and endangered species monitoring onboard the dredges. Open-net turtle trawling was also required during hopper dredging operations for purposes of scaring up turtles from the bottom ahead of the dredges. [Note: There were no turtle incidents during the Nags Head nourishment project-May to October 2011-and a total of five successful nests were laid within town limits in 2011 outside the areas of active construction. Source: Network for Endangered Sea Turtles, NC]

Upon receipt of permits and completion of final design (Kaczkowski \& Kana, this volume), CSE prepared construction plans and bid documents for prospective contractors. Bids were received in February 2011 for a base quantity of 3.0 million cubic yards (mcy) and an additional quantity of up to 1.6 mcy. The metric equivalents are $2.294 \mathrm{mcm}$ and $1.223 \mathrm{mcm}$ (respectively). Great Lakes Dredge \& Dock Company (GLDD) submitted the winning bid which was below the Town's budget, allowing for the maximum permitted volume to be placed $(4.6 \mathrm{mcy}, 3.517 \mathrm{mcm})$.

The construction plan involved the largest cutterhead dredge in the US fleet (GLDD Texas, see www.gldd.com) and three ocean-certified hopper dredges (GLDD Liberty Island, Padre Island, and Dodge Island) at various times with pumpout at two landing sites at any given time, working generally from the center of the project toward the ends. Between 24 May and 27 August 2011, 85 percent of the project volume was in place. Hurricane Irene impacted the project as a Category 1 storm on 27 August. The balance of construction was accomplished by the two smaller hopper dredges by 27 October with numerous no-work days due to weather. Details regarding hurricane impacts are given in a special issue of Shore \& Beach (Watts 2012, Kana et al 2012, McNinch et al 2012).

\section{PRELIMINARY PERFORMANCE}

The initial construction berms were placed at $+1.8-\mathrm{m}$ NAVD with seaward slopes of $\sim 1$ on 13 , which is considerably steeper that the average beach-face slope of 1 on 17 for the project area (CSE 2012). This configuration allowed better control of sections by the contractor and retained the fill within the permitted template. The berm elevation was an average of native dry-beach sections (typical range 1.2-2.6 m) with the goal of rapid overwash and adjustment of the profile under seasonal wave conditions. Hurricane Irene overtopped the berm and shifted small volumes landward to the backbeach area near the base of the foredune. Subsequent fall northeasters and high waves similarly shifted volumes landward across the berm.

The seaward margin of the fill shifted seaward, flattening the beach-face slope and adding volume to the outer bar (Fig 9). Comprehensive surveys after project completion showed that, on average, the entire nourishment volume equilibrated within the $-3.7-\mathrm{m}$ (-12-ft NAVD) contour. Surveys within the project boundaries documented $\sim 4.714$ mcy more sand in the profile in November 2011 compared with November 2010. Net volume changes to various reference contours are given in Figure 10. 


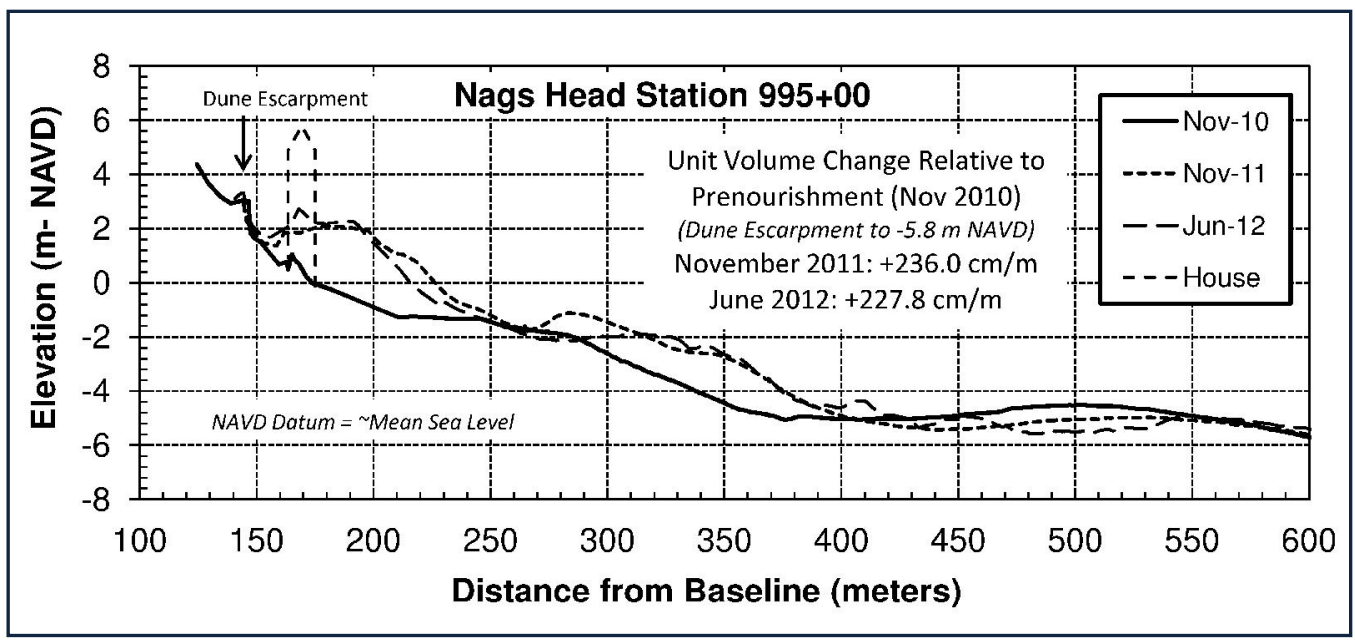

Figure 9. Representative pre-project and post-project profiles for a station along south Nags Head illustrating the fill density and adjustment of the nourished profile more or less retaining the cross-shore morphology of the native beach.

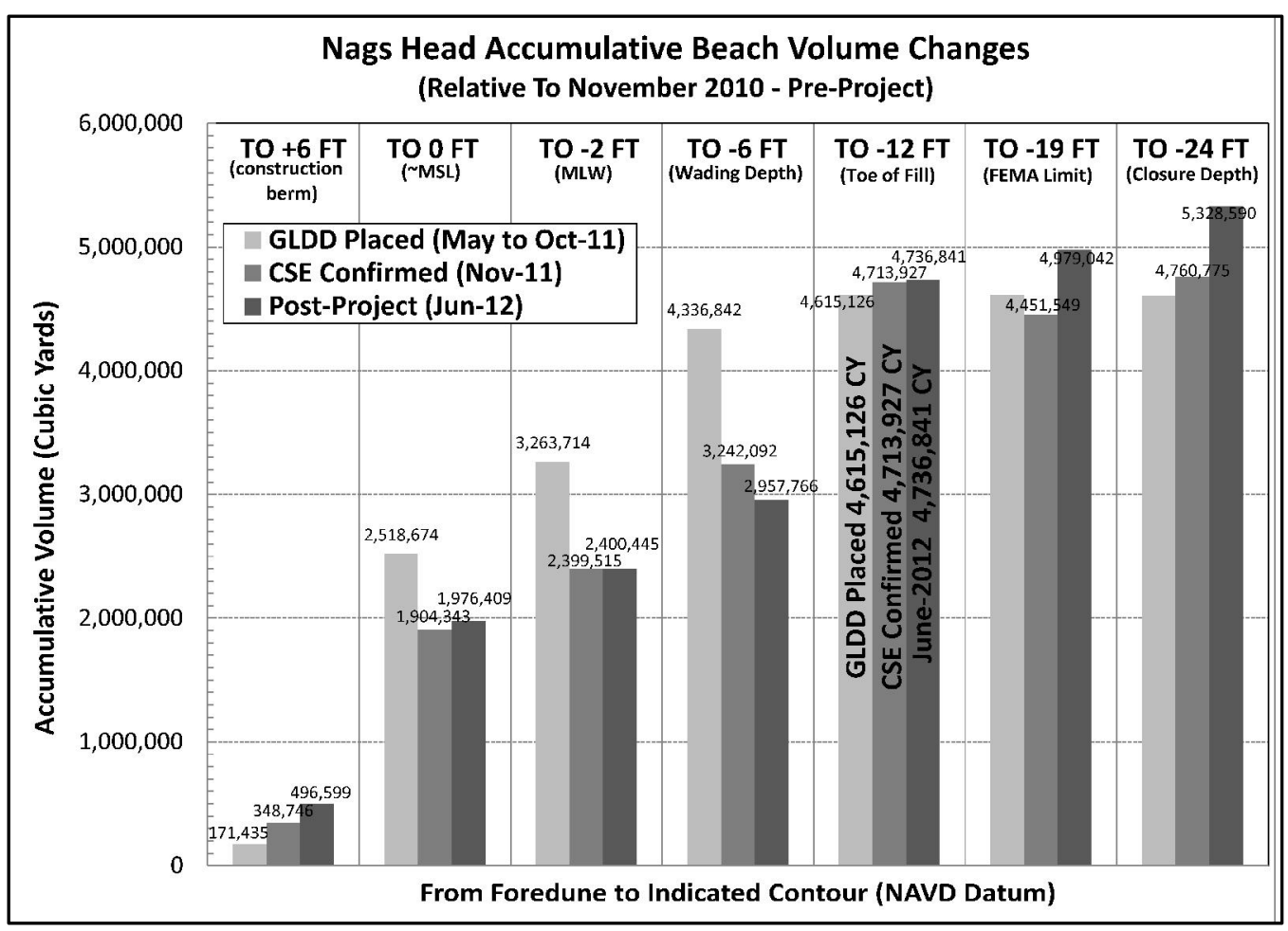

Figure 10. Accumulative beach volumes with respect to pre-nourishment between the foredune and indicated contour (ft NAVD) at initial fill placement and post-project implying rapid project equilibration within the $-12 \mathrm{ft}$ NAVD depth contour.

These preliminary results indicate the initial fill adjustment added $\sim 0.325 \mathrm{mcy}(\sim 0.25 \mathrm{mcm})$ to the dry beach/toe of dune (average $\sim 15 \mathrm{~m}^{3} / \mathrm{m}$ ) via overwash of the berm and aeolian transport. This volume had the beneficial effect of healing dune escarpments and burying exposed sand bags. The shift of sand from the seaward edge of the construction berm to the shallow inshore zone produced a gentler inshore slope with associated favorable impacts on breaker type for recreation.

As of June 2012, there were no net losses of nourishment volume within the project limits measured to $3.66 \mathrm{~m}(-12 \mathrm{ft}$ NAVD). A breakdown of volume changes by reach through June 2012 (Fig 11) indicates there has been a loss of $\sim 12$ percent of the volume placed along Reach 3, a 2,750-m segment in South Nags Head which received the highest fill density (see Kaczkowski and Kana, this 
volume). Reaches 1 and 2 have gained volume since project completion, suggesting the favorable effect of northerly transport observed during periods of high waves from the south. Net transport is southerly along the project area during most years with notable exceptions for some periods as documented by Byrnes et al (2003) and CSE (2011). Any gains in sand volume along Reach 1 are deemed beneficial for project longevity under the influence of net southerly transport over the long term.

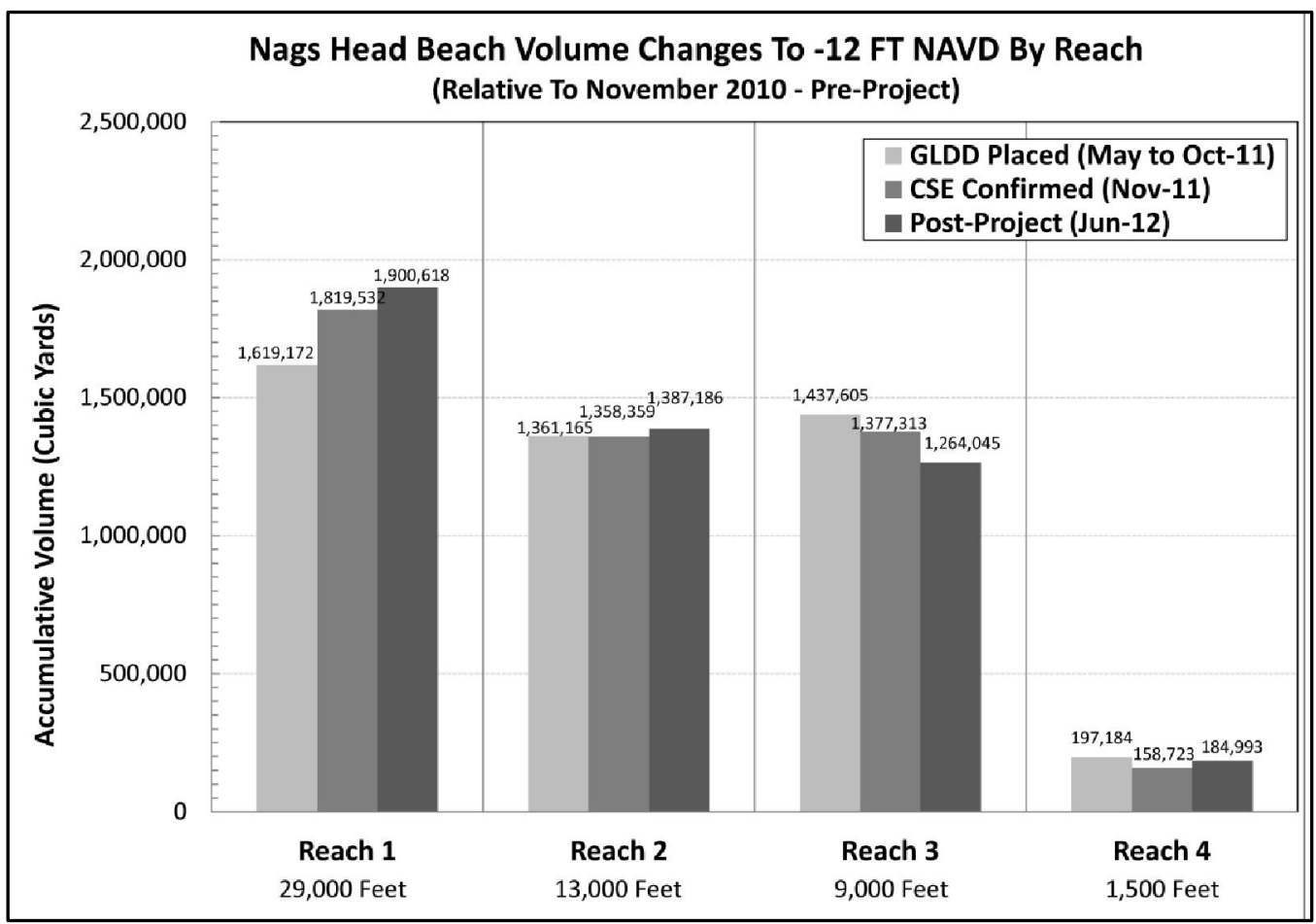

Figure 11. Net beach volume changes by reach with respect to pre-nourishment.

\section{ACKNOWLEDGMENTS}

The Nags Head beach nourishment project was funded by the town of Nags Head and Dare County, North Carolina, through a combination of user fees and property tax revenues. The authors thank the town Board of Commissioners (c/o Mayor Bob Oakes) and town manager (Cliff Ogburn) for spearheading the project. The authors thank the USACE (Raleigh Bland, project manager), NC Department of the Environment and Natural Resources (c/o Doug Huggett) and the state and federal resource agencies for their support of the project. Results herein were based on data collection and analyses prepared with the assistance of Philip McKee, Steven Traynum, Trey Hair, Drew Giles, Dennis Burns, and Diana Sangster. The CSE team especially thanks the contractor, Great Lakes Dredge and Dock Company (area manager Sam Morrison and project manager Dave Allen) and the dredge crews for their efficient construction without incident.

\section{REFERENCES}

Birkemeier, WA. 1985. Field data on seaward limit of profile change. Jour Waterway Port, Coastal and Ocean Engineering, Vol III(3), pp 598-602.

Bocamazo, LM, WG Grosskopf, and FS Buonviato. 2011. Beach nourishment, shoreline change and dune growth at Westhampton Beach, New York, 1996-2009. Journal of Coastal Research, Vol SI-59, pp. 181-199.

Boicourt, WC, et al. 1987. Physics and microbial ecology of a buoyant estuarine plume on the continental shelf. The Oceanography Report EOS, Vol 68, pp 666-668.

Byrnes, MR, RM Hammer, BA Vittor, SW Kelley, DB Snyder, JM Côté, JS Ramsey, TD Thibaut, NW Phillips, JD Wood, and JD Germano. 2003. Collection of environmental data within sand resource areas offshore North Carolina and the environmental implications of sand removal for coastal and beach restoration. US 
Dept Interior, MMS, Leasing Div, Sand and Gravel Unit, Herndon, VA; OCS Rept MMS 2000-056, Vol I (main text $256 \mathrm{pp}$ ), Vol II (appendices $69 \mathrm{pp}$ ).

CSE. 2011. Coastal engineering \& geotechnical analyses for beach nourishment, Nags Head, North Carolina. Final Design Report for Town of Nags Head, NC. CSE, Columbia (SC), 115 pp (incl Executive Summary) + appendices.

CSE. 2012. 2011 Nags Head beach nourishment project. Final Report for Town of Nags Head, NC. CSE, Columbia (SC), $167 \mathrm{pp}+$ appendices.

Clinch, AS, ER Russ, RC Oliver, H Mitasova, MF Overton. 2012. Hurricane Irene and the Pea Island breach: prestorm site characterization and storm surge estimation using geospatial technologies. Shore \& Beach, Vol 80(2), pp 38-46.

Dean, RG. 2002. Beach Nourishment: Theory and Practice. World Scientific, NJ, 399 pp.

Dolan, R, H Lins, and B Hayden. 1988. Mid-Atlantic coastal storms. Jour Coastal Research, Vol 4(3), pp 417433.

Fisher, JJ. 1962. Geomorphic expression of former inlets along the Outer Banks of North Carolina. MS Thesis, University of North Carolina, Chapel Hill, 120 pp.

Hopkins-Murphy, SR, CP Hope, and ME Hoyle. 1999. A history of research and management of the loggerhead turtle (Caretta caretta) on the South Carolina coast. Final Report to US Fish \& Wildlife Service.

James, W.R. 1975. Techniques in evaluating suitability of borrow material for beach nourishment. Rept. No. TM-60, CERC, U.S. Army Waterways Experiment Station, Vicksburg, MS.

Kaczkowski, HL, and TW Kana. 2012. Final design of the Nags Head beach nourishment project using longshore and cross-shore numerical models. In Proc $33^{\text {rd }}$ International Conference on Coastal Engineering (ICCE July 2012, Santander, Spain).

Kana, TW. 1993. The profile volume approach to beach nourishment. In DK Stauble and NC Kraus (eds), Beach Nourishment Engineering and Management Considerations, ASCE, New York, NY, pp. 176-190.

Kana, TW. 1995. Signatures of coastal change at mesoscales. Coastal Dynamics '95, Proceedings of the International Conference on Coastal Research in Terms of Large Scale Experiments, ASCE, New York, NY, pp. 987-997.

Kana, TW, HL Kaczkowski, SB Traynum, and PA McKee. 2012. Impact of Hurricane Irene during the Nags Head beach nourishment project. Shore \& Beach, Vol 80(2), pp 6-18.

Leffler, M, C Baron, B Scarborough, K Hathaway, P Hodges, and C Townsend. 1996. Annual data summary for 1994 CERC Field Research Facility (2 volumes). USACE-WES, Coastal Engineering Research Center, Vicksburg, MS, Tech Rept CERC-96-6.

McNinch, JE, KL Brodie, HM Wadman, KK Hathaway, RK Slocum, RP Mulligan, JL Hanson, and WA Birkemeier. 2012. Observations of wave runup, shoreline hotspot erosion, and sound-side seiching during Hurricane Irene at the Field Research Facility. Shore \& Beach, Vol 80(2), pp 19-37.

NCDENR. 1998, 2004. Long-term average annual shoreline change study and setback factors. NC Department of Environment and Natural Resources, Raleigh (updated Feb 2004) [see http://dcm2.enr.state.nc.us/maps/ER_1998/SB_Factor.htm]

NMFS. 1997. Regional biological opinion concerning the use of hopper dredges in channels and borrow areas along the southeast U.S. Atlantic coast. National Marine Fisheries Service, Silver Spring, MD, 16 pp.

USACE. 2000 (Sep). Final feasibility report and environmental impact statement on hurricane protection and beach erosion control: Dare County beaches (Bodie Island portion), Dare County, North Carolina. Vol I and Vol II, US Army Corps of Engineers, Wilmington District, South Atlantic Division, $99 \mathrm{pp}+$ appendices.

USACE. 2010 (MAY). Final environmental impact statement, beach nourishment project, Town of Nags Head, North Carolina. US Army Corps of Engineers, Wilmington District, Washington Regulatory Field Office, NC (Action ID SAW-2006-40282-182), 164 pp+ executive summary, references, and appendices.

Verhagen, HJ. 1992. Method for artificial beach nourishment. In Proc $23^{\text {rd }}$ Intl Coastal Engineering Conf, ASCE, New York, NY, pp 2474-2485.

Watts, IM. 2012. Hurricane Irene storm overview. Shore \& Beach, Vol 80(2), pp 4-5. 